\section{AN AESTHESIA IN MIDWIFERY.}

To the Elitor of THE LANCEr.

SrR, - In the report of the proceedings of the Obstetrical Society of London contained in your last number it is stated that Dr. Priestley considered my apparatus too fragile for the purpose of administering chloroform. Allow me here to ob. serve that my answer to Dr. Priestley is not given-namely, that before giving his opinion it would be better that he first handled it (he had only seen it at a distance when he said so). I would further remark that what he did see was an apparatus of my own rude construction, which had unfortunately met with an accident before exhibiting it to the Society. As I have had an extensive experience of the practical strength and general utility of the apparatus, I beg to state that it is in nowise fragile, but will stand with impunity the roughest usage it is ever likely to meet with. In point of economy, it saves from 60 to $70 \mathrm{per}$ cent. of chloroform.

I very much regret that, from unavoidable circumstances, I was too late in sending an abstract of my paper to the Secretary of the Society for publication in your pages. Let me trust that I am not too late to be allowed to state that since my paper was read I have succeeded in getting my apparatus made to my entire satisfaction, if not greatly improved, by Messrs. Maw and Son, of 11, Aldersgate-street, London, where specimens may be seen, as also in their cases at the International Exhibition, Kensington. Two kinds have been made by them -one for carrying in the crown of the hat, and another for a leather case.

I remain, Sir, your very obedient servant,

Liverpool, May, 1862.

Thomas Srinner, M.D.

\section{THE MEDICAL PROFESSION AND LIFE ASSURANCE OFFICES.}

To the Editor of THE LANCET.

SrR,-The "Atlas" and the "Consolidated" Life Assurance Societies must be excluded from the list of offices which pay medical practitioners for their reports on the lives of patients. Within the last two or three months I have received the usual printed form of queries to be answered by the medical attendant from both these offices, but neither fee nor promise to pay one accompanied the letter. I followed my usual practice, by im. mediately returning to the secretaries or actuaries the papers, endorsed with the information that I should be happy to de. vote my time to the matter, and give my professional experience as to the eligibility of the proposed lives for assurance, upon receipt of the fee of one guinea. I received no reply, nor have I yet taken the trouble to inquire whether my patients' lives were accepted.

As it is so very desirable that the profession should be sup plied with a correct list of offices paying their private medical referees, it is to be hoped that practitioners will comply with the request contained in your leading article of March 15 th, and forward to you from time to time the names of the nonpaying offices.

I am, Sir, your obedient servant,

Yealand Conyers, near Lancaster, May, 1862, P. ALlEN, M.D.

\section{MIDWIFERY STATISTICS. \\ To the Editor of The Lancet.}

Sir, - The following remarks are formed from note-books extending over a period of twenty years' practice, and embracing 3381 cases in inidwifery :-

The head presented in the second position (left side of the head) in nineteen cases.

Nates presentations numbered twenty-nine cases; footling, twenty-one.

The cheek presented five times.

Arm and shoulder presented seven times.

The cord was found prolapsed in four patients.

Placenta prævia occurred six times--(four partial, two com-

plete).

Twins presented thirteen times; triplets bat once.

Monstrosities occurred four times.

The forceps were used in twenty. two cases.

Turning was performed twelve times.

Craviotomy was resorted to in eleven cases.

Spontaneous evolution occurred in one case.

The youngest patient wanted three weeks to complete her fourteenth year; the eldest $\mathrm{v}$ as forty-five years of age.
The shortest cord measured five inches; the longest fifty. eight. The cord had double knots on it in three cases; and single knots in four.

Encysted placenta happened in fifteen cases, the lower seg. ment of the uterus near the os internum being generally the at of stricture.

In one case of twins the first child was born at twenty minutes to seven in the evening, the second at ten minutes past ten the following morning. No pains occurred during this ong interval, and I could not persuade the patient that a second child was in utero.

I am, Sir, your obedient servant,

Paddington-green, May, 1862. JoHN H. Beale, M.R.C.S.

\section{CONSULTATIONS WITH HOMGEOPATHS.} To the Editor of THE LANCET.

SIR, - The note of "Inquirer" in last week's LANCET respecting Dr. Clay and his consultations with homeopaths touches on a matter that wants explanation.

Dr. Clay cloes meet honœopaths, and I believe regularly. Three instances of deliberate consultation have occurred within my own knowledge.

Manchester, May, 1862. I am, Sir, yours, \&c., Respondent.
P.S.-I enclose my card.

\section{PARISTAN MEDICAL INTELLIGENCE.}

(FROM OUR SPECIAL CORRESPONDENT.)

A Funeral oration pronounced at the tomb of MT. Breton. neau by the oldest and certainly not the least distinguished of his disciples, M. Velpeau, merits some notice as happily portraying the leading characteristics of the illustrious medical veteran of Tours who has recently passed from amongst us. "His great reputation," observed M. Velpeau, "was due neither to a fortuitous combination of circumstances, nor to the influence and interest of the great. The celebrity he attained was unsought by himself, and was unconnected with either academical triumph or popularity hunting. Absorbed by the pursuit of science, and at a distance from the social crises of his generation, he acquired fame unwittingly. In order to be just to Bretonneau, his character should not be estimated by the common standard of men; his life, his thoughts, his actions, were wholly unlike those of others. His hours for work were irregular, as were his times for repose and refreshment. When an object or occupation arrested his fancy, his pursuit was incessant and untiring. Whilst engaged in the investigation of typhoid fever and diphtheria, he would turn his back on those who spoke to him of any other subject. If the bell rang, he would say to me, 'Go, my friend, and inquire whether the case be one of either sore-throat or fever: if so, I shall attend immediately; if otherwise, say that I am not at home.' Did he, on returning from his morning visit to the hospital, by chance step into his garden, his patients were no longer thought of, and his mind became absorbed by his vegetables, his grafts, and his settings. In operating for cataract on one occasion, he found that the form of needle then in use was inconvenient : he immediately set about inventing another (that now commonly employed). For fear of being misunderstood by the workman, he insisted on forging it himself, and for three days could not be persuaded to leave his workshop. A similar occurrence took place with regard to certain vaccine tubes. When interested in a case, he would remain for hours at the bedside of a patient, returning as often as he believed any knowledge was to be gained from the study of the particular malady. His object was neither the gratification of vanity, nor glory; but simply the extension of science and truth. During the epidemics of sore-throat and fever, his brother. practitioners, in refutation of his doctrines, maintained that the morbid appearances observed by Bretonneau at the hospital differed from those noticed in private practice. To obtain autopsies with the consent of the friends of the deceased was most difficult; nevertheless, Bretonneau was determined to carry his point, and, with my assistance, at night, no less than thirty six post-mortem examinations were clandestinely obtained by exhumation of the dead. On more than one oucasion our profanations were suspected, and we were fired upon. I have every reason to remember the circumstances, from the 